\title{
Numerical Study on Thermal Comfort-A Case Study Using Taguchi Method
}

\author{
Sheetal Kumar Jain ${ }^{1}$, Manish Dadhich², Vikas Sharma², Sanjay Kumar Sharma ${ }^{2}$, \\ Dhirendra Agarwal ${ }^{3}$, Rahul Gupta ${ }^{4}$ \\ ${ }^{1}$ Apex Institute Of Engineering and Technology, Jaipur, Rajasthan, India \\ ${ }^{2}$ Grob Design Pvt. Ltd., Jaipur, Rajasthan, India \\ ${ }^{3}$ FET Agra College, Agra, Uttar Pradesh, India \\ ${ }^{4}$ Global Institute of Technology, Jaipur
}

\begin{abstract}
:
Thermal comfort is the major factor responsible for the refinement of ventilation of an office. Installation of fans inside the room greatly affects the overall air circulation of the room. The effect of Evaporative cooling with internal fans is simulated under various conditions for an office building located in Jaipur, Rajasthan (India). Thermal comfort parameters are used for analysis: Cooling air speed. CFD studies were carried out by using the ANSYS FLUENT 14.5 to find the effect of inlet air speed, presence of heat source inside the building. For analysis, turbulence model ( $k-\varepsilon$ model) was used. Under radiation model, Rosseland model was used. Boundary conditions are given for the inlet, internal fans and outlet. All experiments are designed using Taguchi methods and orthogonal array methods to get better overall results.
\end{abstract}

\section{Keywords:}

CFD, Thermal Comfort, Internal Fans, Cooling Speed

\section{Introduction:}

Botheration about indoor air quality and human comfort has intensified the research to increase the Potential of natural ventilation to cool and ventilate buildings especially in temperate climates like Jaipur in Rajasthan. In these areas natural ventilation is not enough to achieve the desired room temperature. In many developed countries, a part of the primary energy use goes towards maintaining a pleasant indoor environment.

Air conditioning, evaporative cooling, blowers and internal fans are various devices installed in a building to maintain room temperature [1], [2] \& [3]. In present study, evaporative coolers along with internal fans have been used to increase the thermal comfort and quality of air inside the building [4], [9] \& [10]. Evaporative cooling is simply the reduction in temperature resulting from the evaporation of a liquid, which removes latent heat from the surface from which evaporation takes place [5], [6]. This process is employed in industrial and domestic cooling systems. Simulations were carried out through CFD analysis. CFD studies have been benchmarked against small scale laboratory experiments, wind tunnel studies, full-scale tests, and zone modelling software [7], [8].

Dr. Taguchi of Nippon Telephones and Telegraph Company, Japan has developed a method based on orthogonal array experiments which gives much reduced variance for the experiment with optimum settings of control parameters. Orthogonal Arrays provide a set of well balanced (minimum) experiments and Dr. Taguchi's Signal-to-Noise ratios $(\mathrm{S} / \mathrm{N})$, which are log functions 
of desired output, serve as objective functions for optimization, help in data analysis and prediction of optimum results. Taguchi method is useful for tuning the process for best results. In the present study, taguchi method has been used to obtain the best set of experiments from various cases having variable values of parameters.

In present study CFD simulation was carried out for four cases of design of office as shown in figure. Main focus was on air inlet boundary condition of office. In this study a window area 21 inch $\mathrm{x} 21$ inch was used for air inlet conditions based on desert cooler cross section. Office walls are assumed to be made by brick wall material with insulation at proper places of vertical external walls. Thickness of walls are assumed 9 inch. Internal partition was made of Aluminium frame with glass sheets.

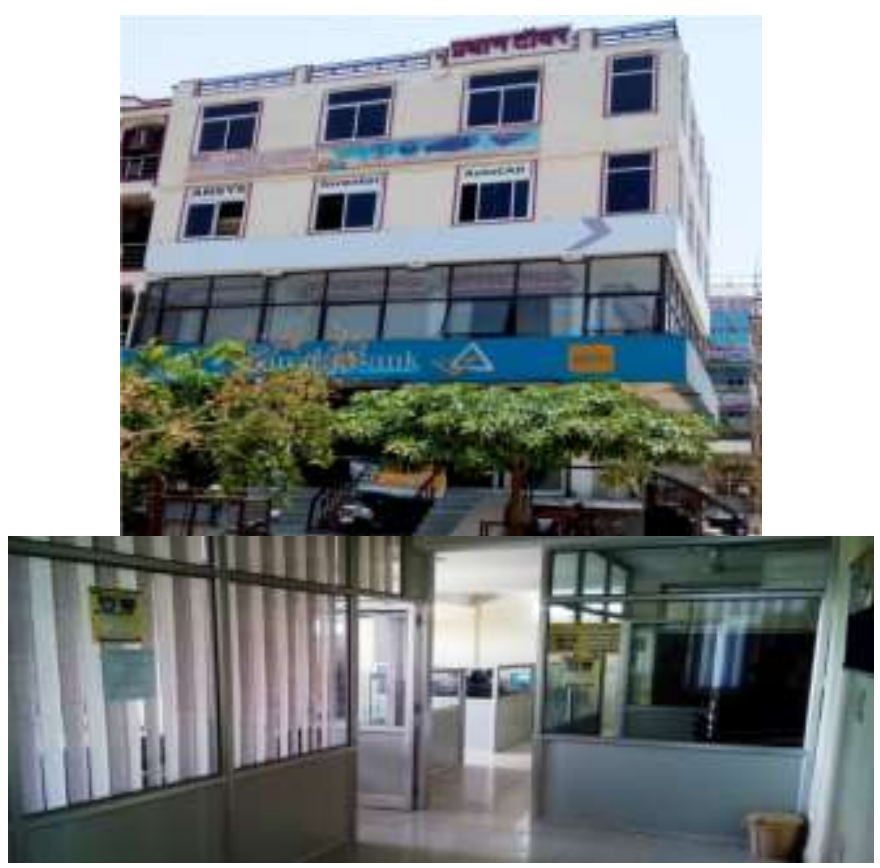

Fig 1: Office building under consideration for simulation

\section{Abbreviations and Acronyms:}

- F13- location of point under fan 1 at 3 feet.

- F15- - location of point under fan 1 at 5 feet.

- F23- location of point under fan 2 at 3 feet

- F25- location of point under fan 2 at 5 feet

- F33- location of point under fan 3 at 3 feet

- F35- location of point under fan 3 at 5 feet

- $\mathrm{SN}$ ratio- signal to noise ratio.

\section{Experimental:}

\section{CFD modelling}

Computational fluid dynamics (CFD) is a branch of science which predicts the fluid flow, heat and mass transfer, chemical reactions, and any other related physical phenomenon. CFD solves various governing equations for conservation of mass, momentum, energy, turbulence and 
various other transport state equations. The CFD modelling is done on ANSYS FLUENT 14.5. CFD modelling solves the mass momentum and energy equations by dividing the solution domain into many computational cells. CFD modelling provides more accurate results than other techniques. The Bousinessq assumption was applied to represent the buoyancy force, and the renormalization group, (RNG) and k- $\varepsilon$ model was employed to approximate turbulence. Gan implemented a parametric investigation of airflow rates in a three-dimensional Trombe wall using the RNG k- $\varepsilon$ model. Basically there are three steps in CFD modelling as follows:

\section{A. Pre-processing:}

The major steps involved in pre processing are:

Geometrical details - First of all geometry of the office building was created using Autodesk Inventor 2014 (a CAD software). The length of the building 35ft. The width of the building $30 \mathrm{ft}$. The height of the building is $10 \mathrm{ft}$. The figure is shown below.

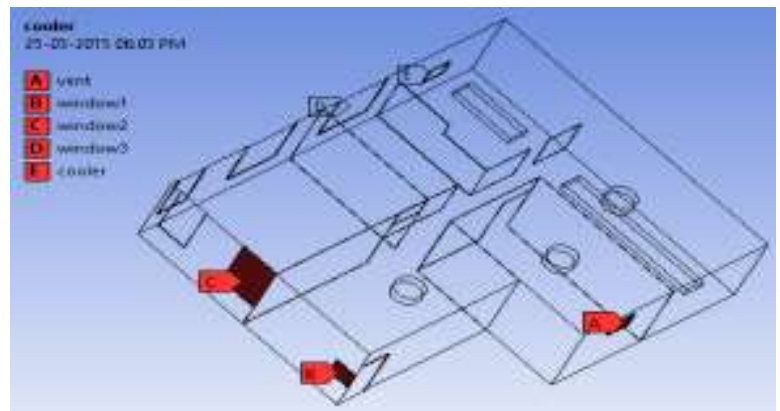

Fig. 2: Geometrical representation of office building

Mesh generation- Meshing is the discretization of the domain into control volumes. Various transport equations are solved for these control volumes. In this study hex-dominant mesh method was used.

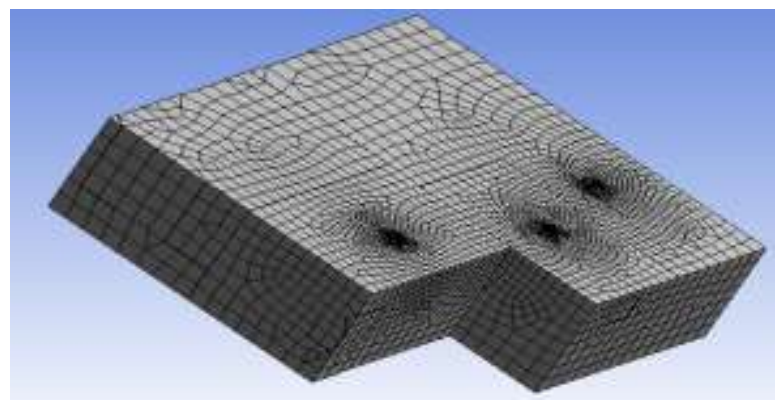

Fig. 3: Mesh representation of the office building.

Model- In this study three type of governing equations were solved named continuity equations, momentum equations and energy equations. But in ANSYS fluent these equations were dependent on model selection. Viscous modelling shows turbulence solutions for CFD domains, author select K-e RNG turbulence model for this purpose. Radiation model (Rosseland model) was used.

Material properties- Air is taken as the fluid medium. The room walls are made of bricks. Internal partition was made of Aluminum frame with glass sheets.

\section{B. Solver-}

Various governing equations namely continuity equation, energy equations and momentum equations are solved on the mesh by solver.

\section{Post processing-}


Under post processing, contours, streamlines and graphs are used to infer the results.

\section{Numerical Simulation and Problem Identification:}

According to ANSYS CFD 14.5, it is a complete suite of perfect tools for simulating, analyzing, optimizing and validating machining products used by various industries. This software addresses the broadest range of manufacturing issues and design geometry types associated with machining processes.

There are three stages of the simulation in CFD. The first stage of a Finite Volume (FV) method based simulation is called "pre-process". This can be performed by using either the simulation software itself or one of the Computer-Aided Design (CAD) computer programs such as Autodesk Inventor, and Auto-cad. The geometric model is then meshed using triangular mesh elements (automatic mesh generation).To finish this first stage, it is required to set the process conditions into the simulation software. In the second stage of a simulation process, various governing equations are performed and applied to a model analysis. The last stage of a FVM simulation is called "post-process", where the experience of the analyst is required to extract the reliable and most important information from multiples coloured contour results offered by the simulation software Pre-process is very important for the efficiency of the simulation model. Hence, it must be thoroughly analyzed on the part geometry and its conditions as described in the following section.

\section{Problem Description}

The problem focused in this study is to apply statics methods to improve thermal comfort of an office building. In this study of office building, three process parameters named cooling temp, intake fan on and window opening with three levels and Taguchi table were used for design of experiment. Initial temperature of room $313 \mathrm{~K}$ is considered. The simulation is made for one hour (12PM-1PM).

\section{Process Parameters:}

\begin{tabular}{|c|c|c|c|}
\hline $\begin{array}{c}\text { Facto } \\
\mathbf{r} / \\
\text { Level }\end{array}$ & $\begin{array}{c}\text { Cooling } \\
\text { temp } \\
(\mathbf{0} \mathbf{c})\end{array}$ & $\begin{array}{c}\text { Intake } \\
\text { fan on }\end{array}$ & $\begin{array}{c}\text { Window } \\
\text { open }\end{array}$ \\
\hline 1 & 26 & 1 & 1 \\
\hline 2 & 28 & 2 & 2 \\
\hline 3 & 30 & 3 & 3 \\
\hline
\end{tabular}

Table 1: Summary of all levels and their factors

\begin{tabular}{|c|c|c|c|}
\hline Case No. & $\begin{array}{c}\text { Cooling temp } \\
(\mathbf{0})\end{array}$ & Intake fan on & $\begin{array}{c}\text { Window } \\
\text { open }\end{array}$ \\
\hline 1 & 26 & 1 & 1 \\
\hline 2 & 26 & 2 & 2 \\
\hline 3 & 26 & 3 & 3 \\
\hline 4 & 28 & 1 & 2 \\
\hline 5 & 28 & 2 & 3 \\
\hline 6 & 28 & 3 & 1 \\
\hline 7 & 30 & 1 & 3 \\
\hline 8 & 30 & 2 & 1 \\
\hline 9 & 30 & 3 & 2 \\
\hline
\end{tabular}


Table 2: orthogonal array Taguchi Table

\section{Results and Discussions}

Results are shown for the different cases for temperature and velocity with time which are simulated by CFD.

\section{Case-1}

The cooling temperature is taken as $26^{\circ} \mathrm{C}$. One intake fan is working and only one window is open. The velocity and temperature at various points inside the office building is shown below:

\section{For Velocity-}

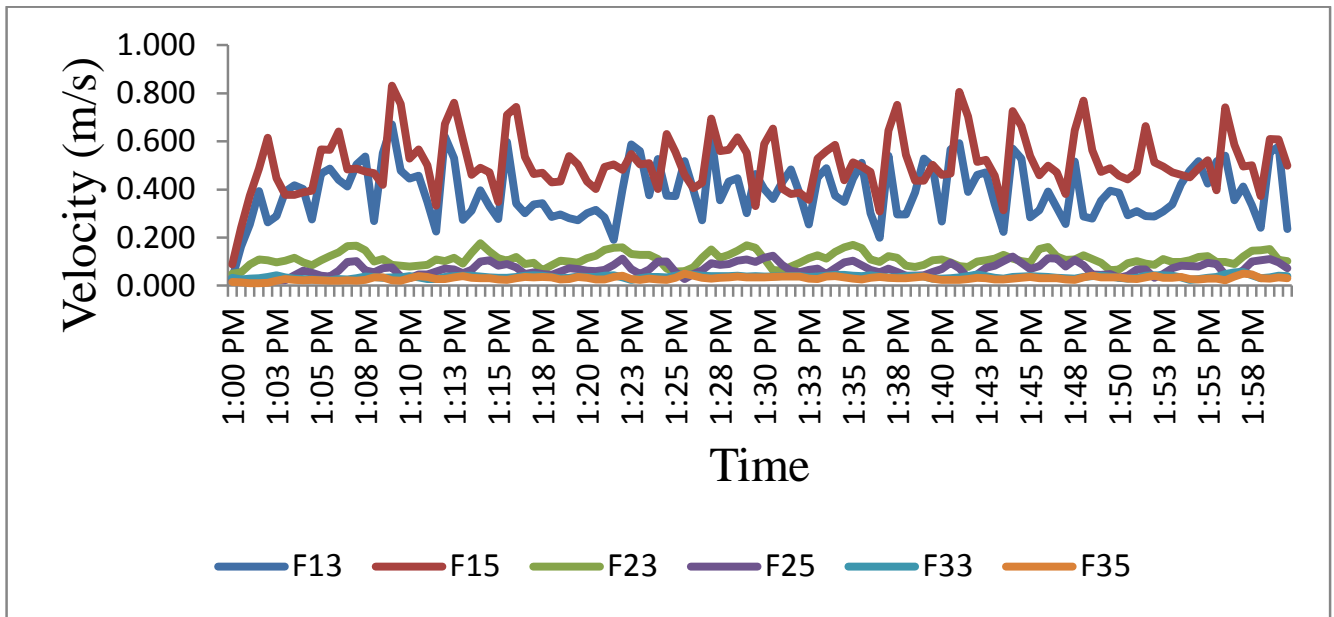

Fig. 4: Velocity vs. time

The increase in velocity is due to thermal buoyancy. This causes sudden increase in velocity at different points inside the room.

\section{For Temperature-}

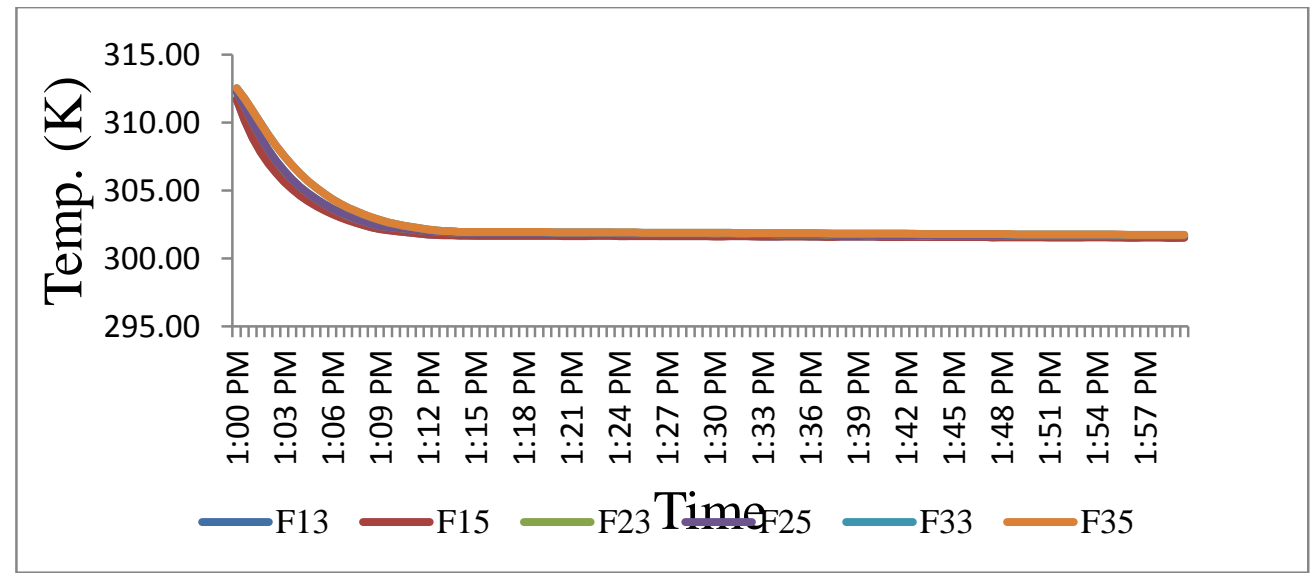

Fig. 5: Temperature vs. Time

\section{Case-2}


The cooling temperature is taken as $26^{\circ} \mathrm{C}$. Two intake fans are working and two windows are open. The velocity and temperature at various points inside the office building is shown below:

\section{For Velocity-}

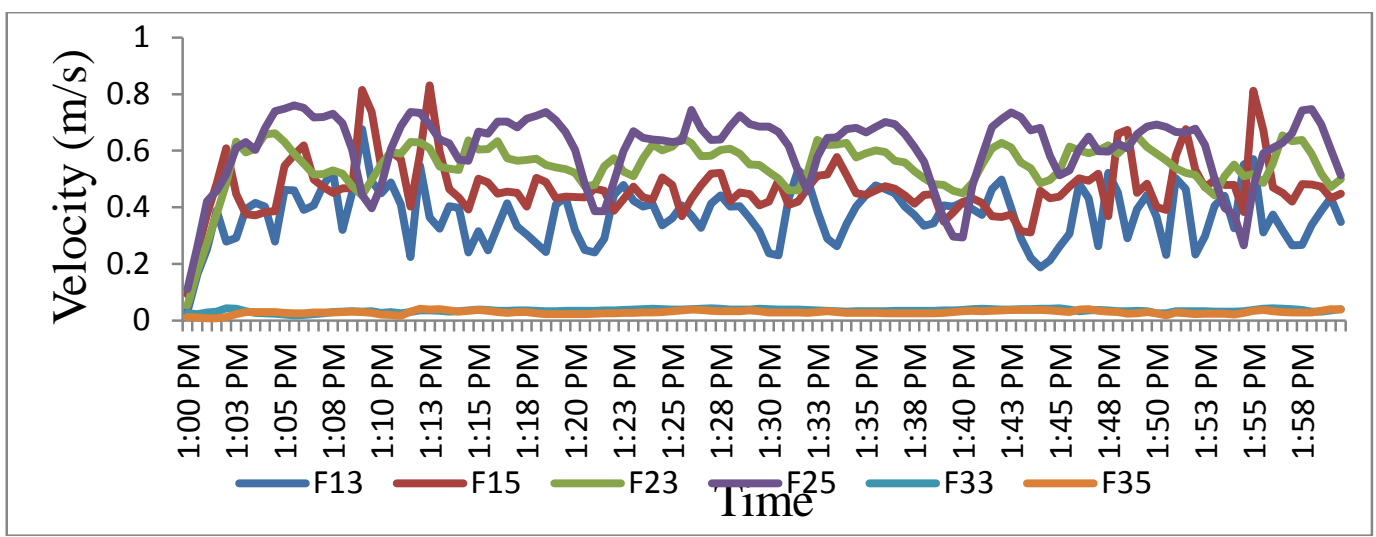

For Temperature-

Fig. 6: Velocity vs. time

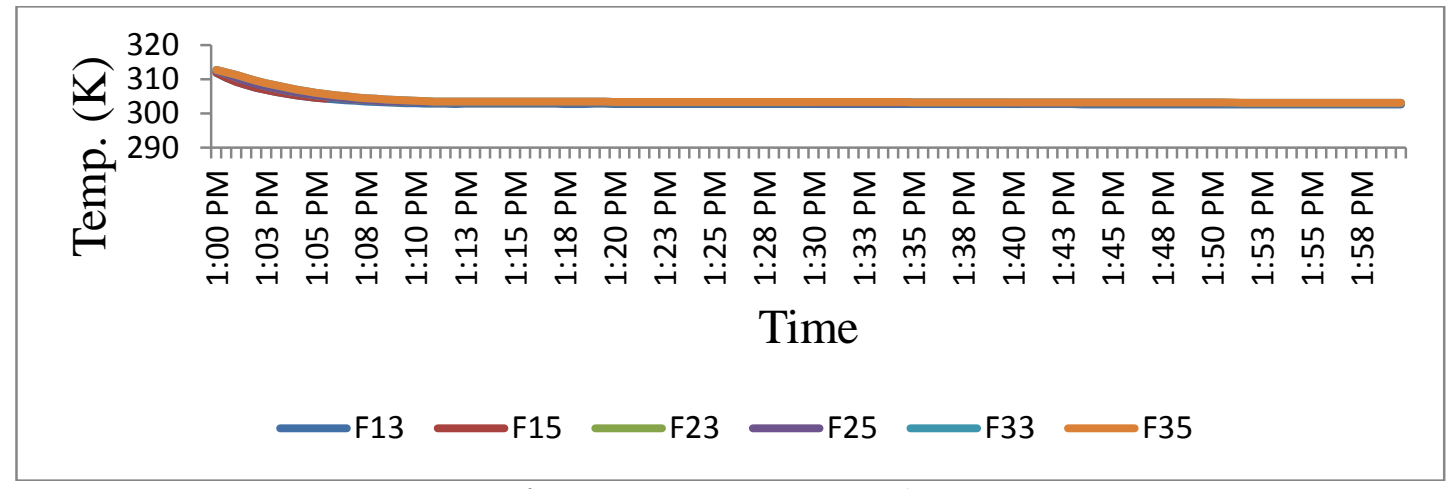

\section{Case-3}

Fig. 7: . Temperature vs. time

The cooling temperature is taken as $26^{\circ} \mathrm{C}$. Three intake fans are working and three windows are open. The velocity and temperature at various points inside the office building is shown below:

\section{For Velocity-}

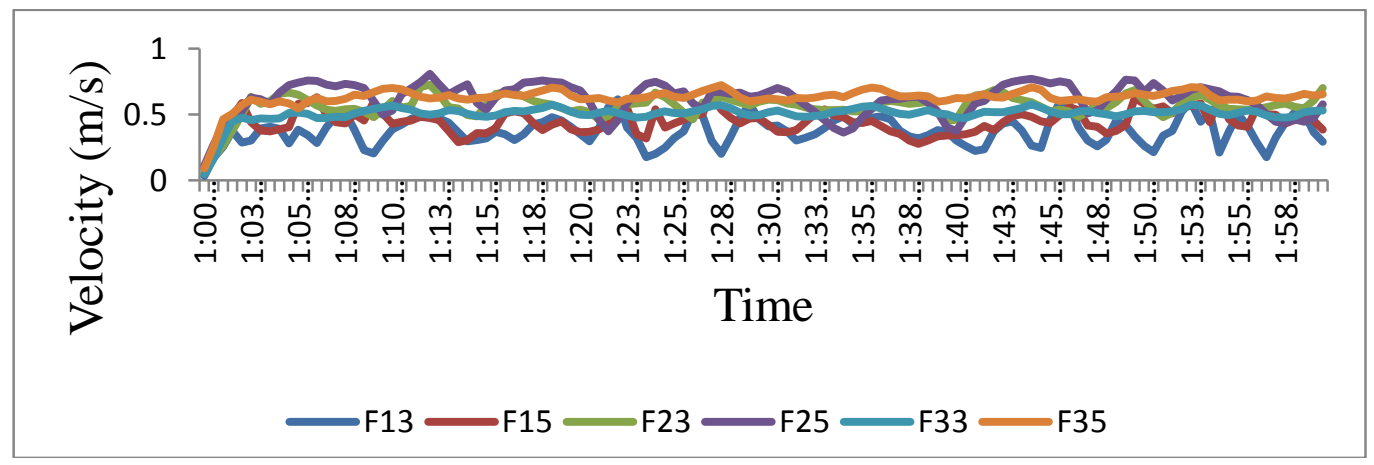

Fig. 8: Velocity vs. time 


\section{For Temperature-}

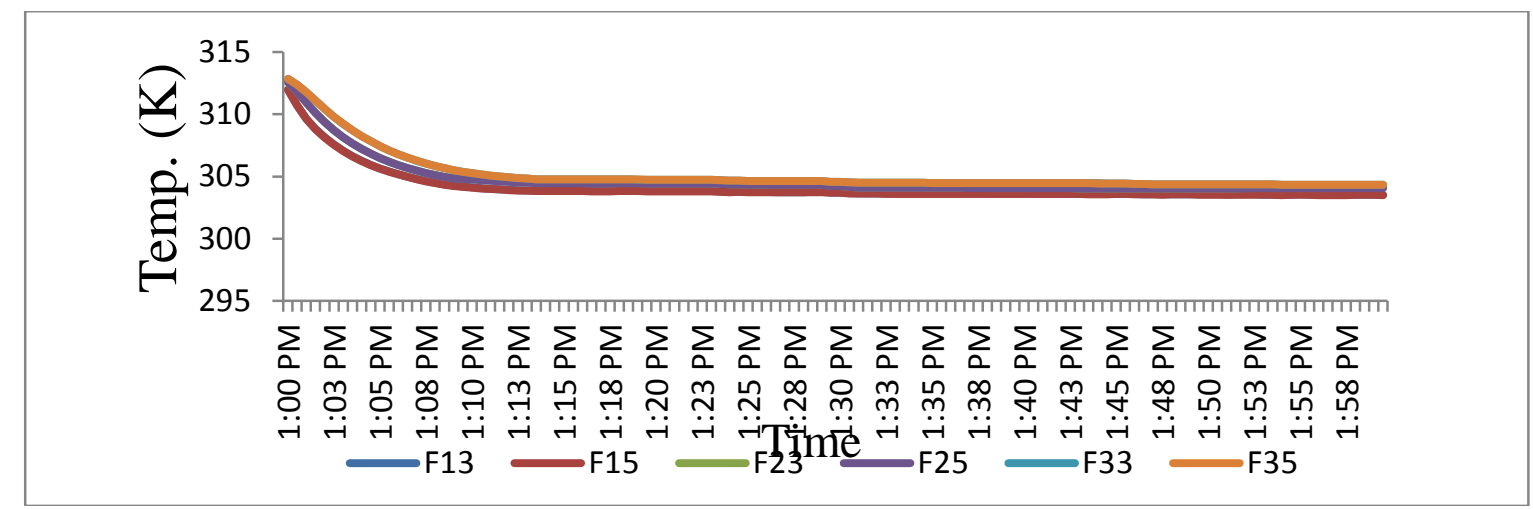

Fig. 9: Temperature vs. time

\section{Case-4}

The cooling temperature is taken as $28^{\circ} \mathrm{C}$. One intake fan is working and two windows are open. The velocity and temperature at various points inside the office building is shown below:

\section{For Velocity-}

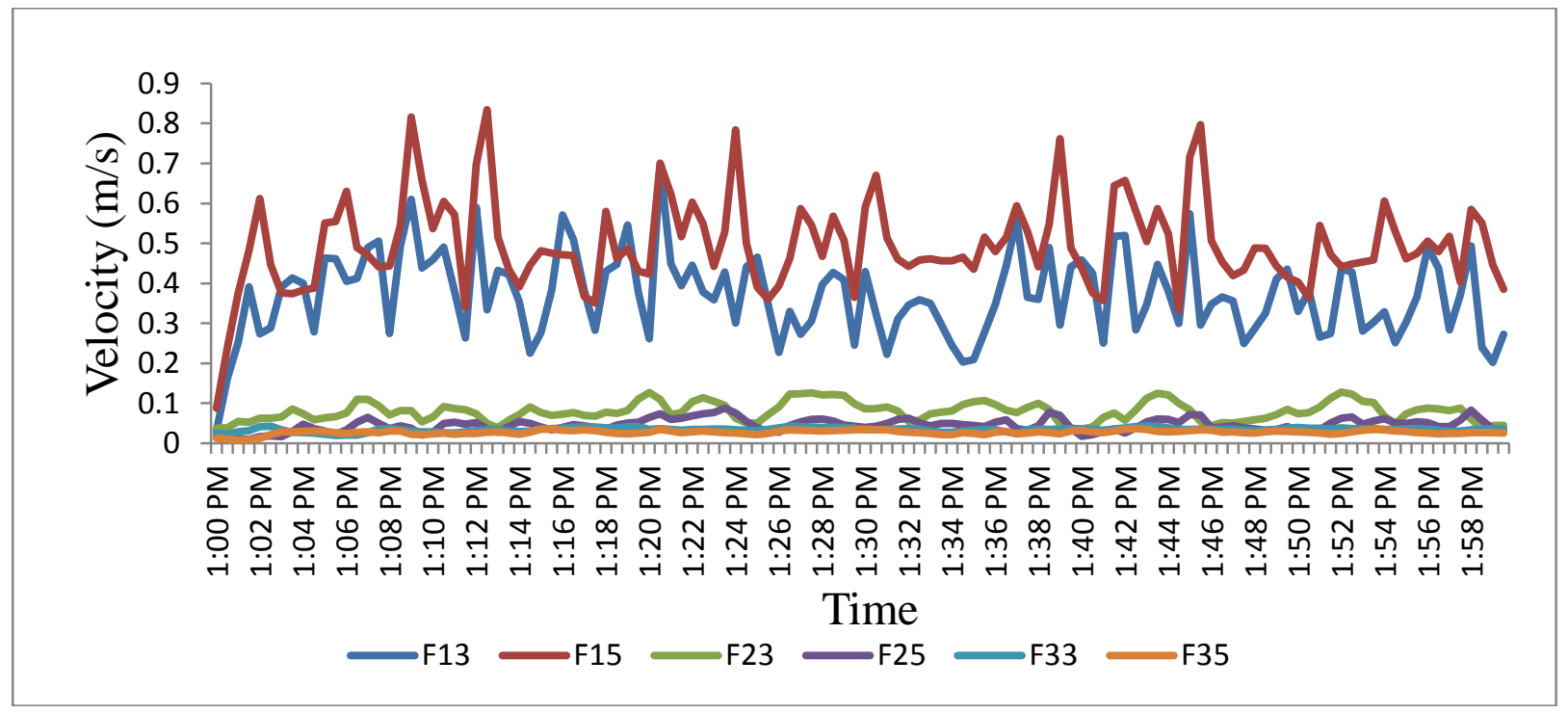

Fig. 10: Velocity vs. Time 


\section{For Temperature-}

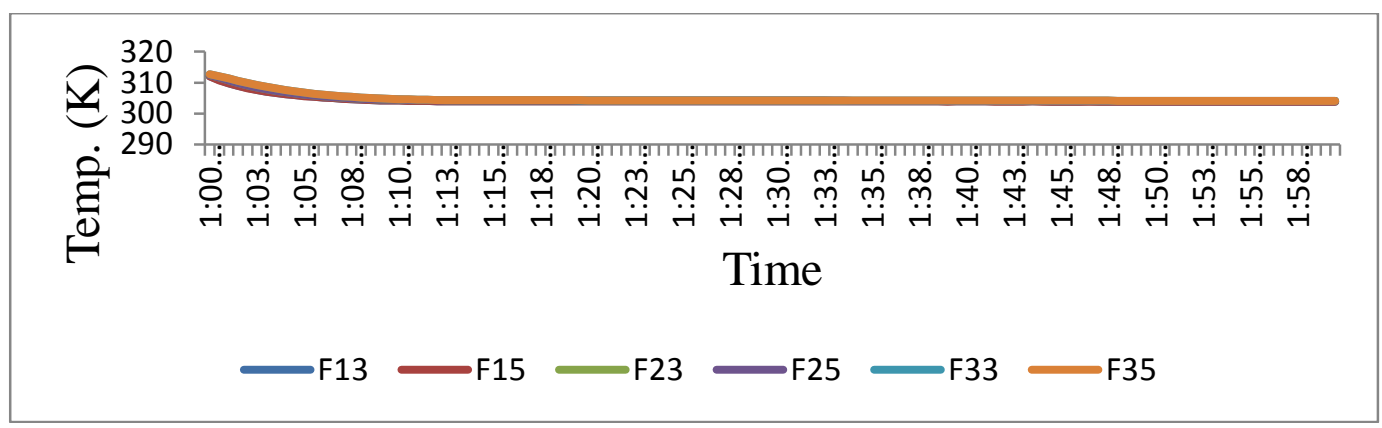

\section{Case-5}

Fig. 11:. Temperature vs. time

The cooling temperature is taken as $28^{\circ} \mathrm{C}$. Two intake fans are working and three windows are open. The velocity and temperature at various points inside the office building is shown below:

\section{For Velocity-}

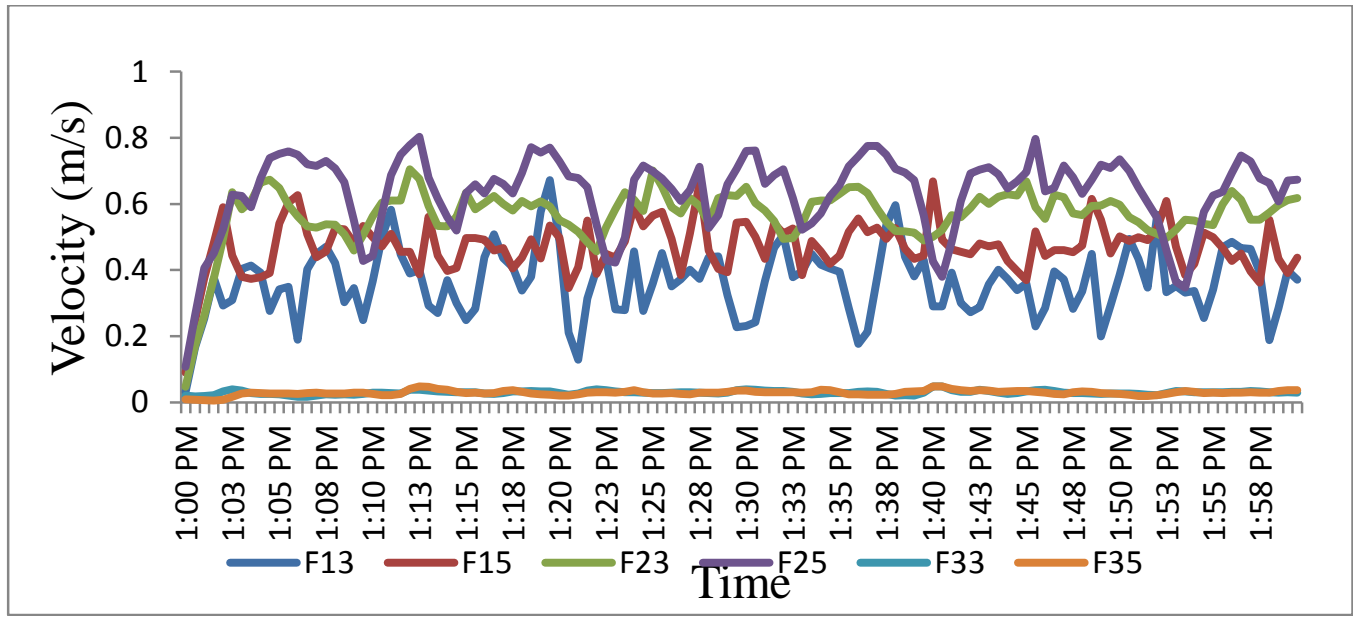

\section{For Temperature-}

Fig. 12: Velocity vs. time

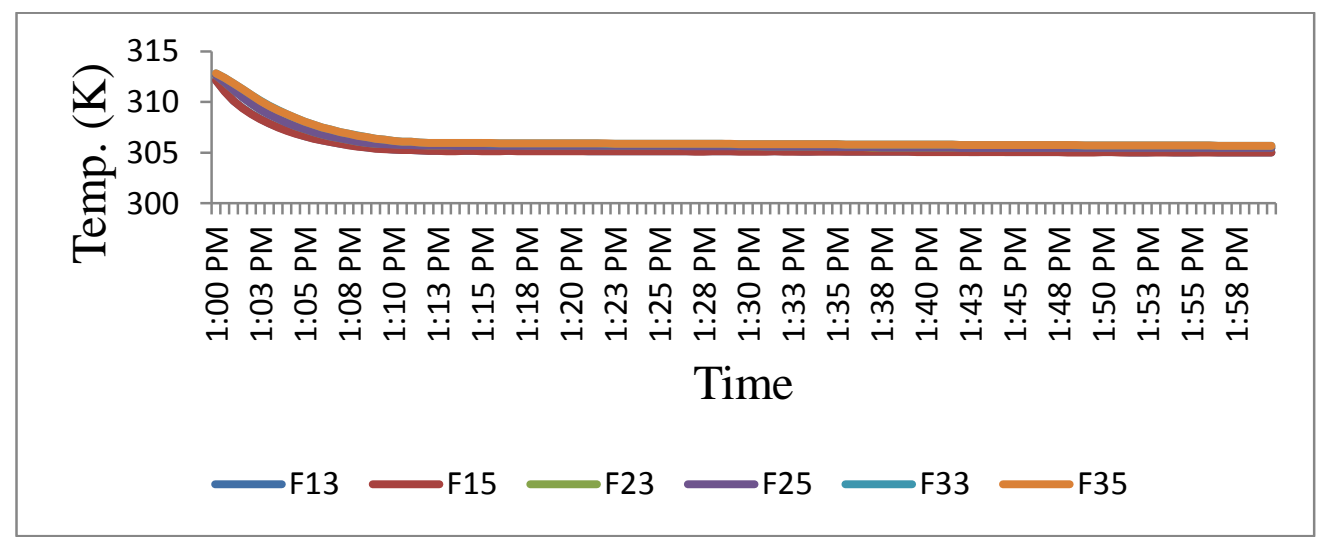


Fig. 13: Temperature vs. time

\section{Case-6}

The cooling temperature is taken as $28^{\circ} \mathrm{C}$. Three intake fans are working and one window is open. The velocity and temperature at various points inside the office building is shown below:

\section{For Velocity-}

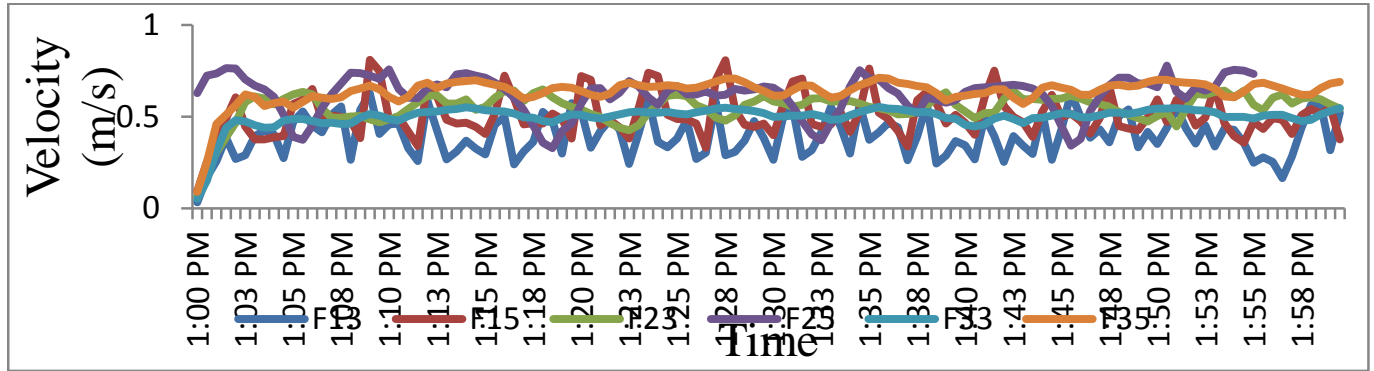

Fig. 14: Velocity vs. time

\section{For Temperature-}

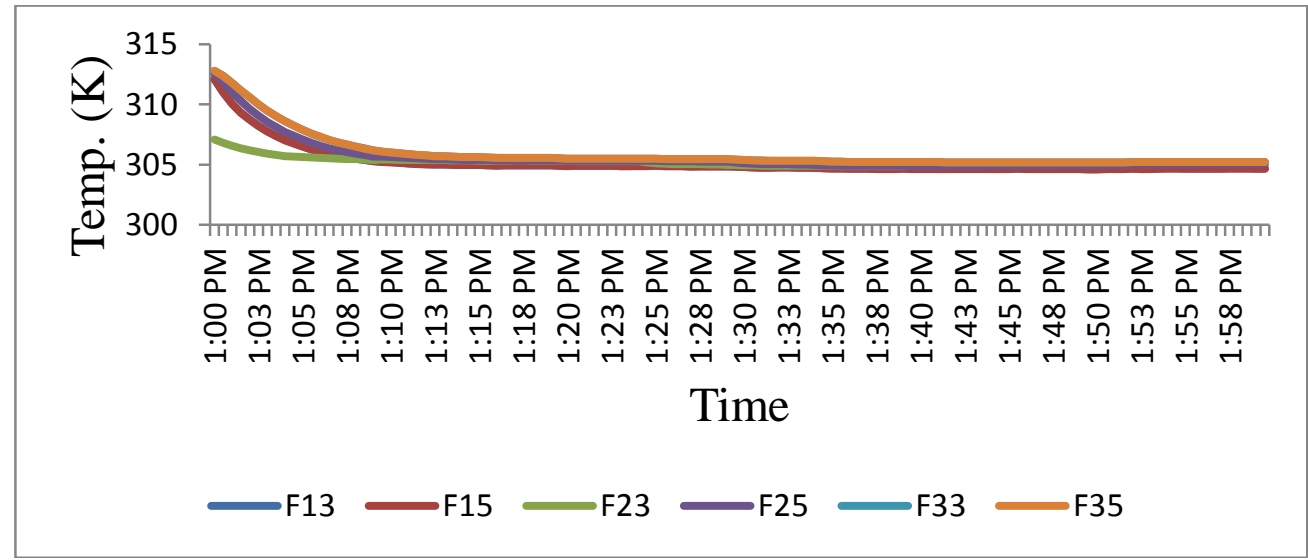

Case-7

Fig. 15: . Temperature vs. time

The cooling temperature is taken as $30^{\circ} \mathrm{C}$. One intake fan is working and three windows are open. The velocity and temperature at various points inside the office building is shown below:

\section{For Velocity-}

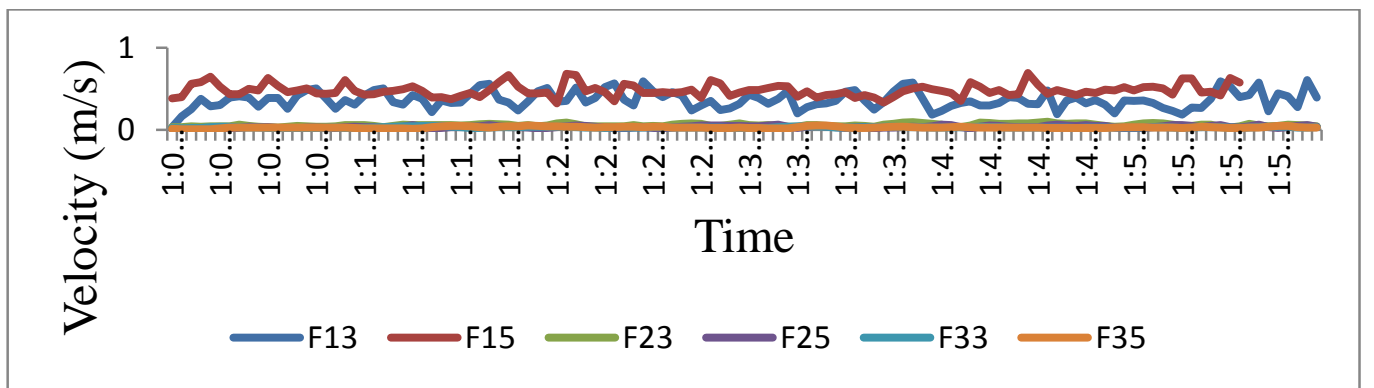


Fig. 16: Velocity vs. time

\section{For Temperature-}

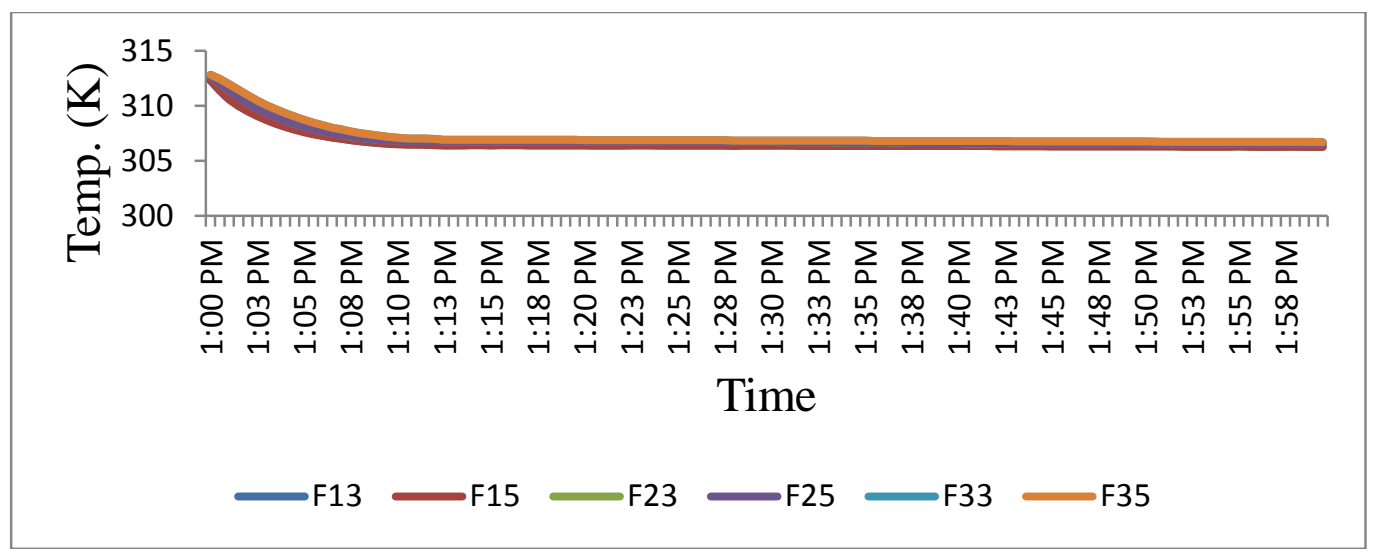

Fig. 17: Temperature vs. time

\section{Case-8}

The cooling temperature is taken as $30^{\circ} \mathrm{C}$. Three intake fans are working and one window is open. The velocity and temperature at various points inside the office building is shown below:

\section{For Velocity-}

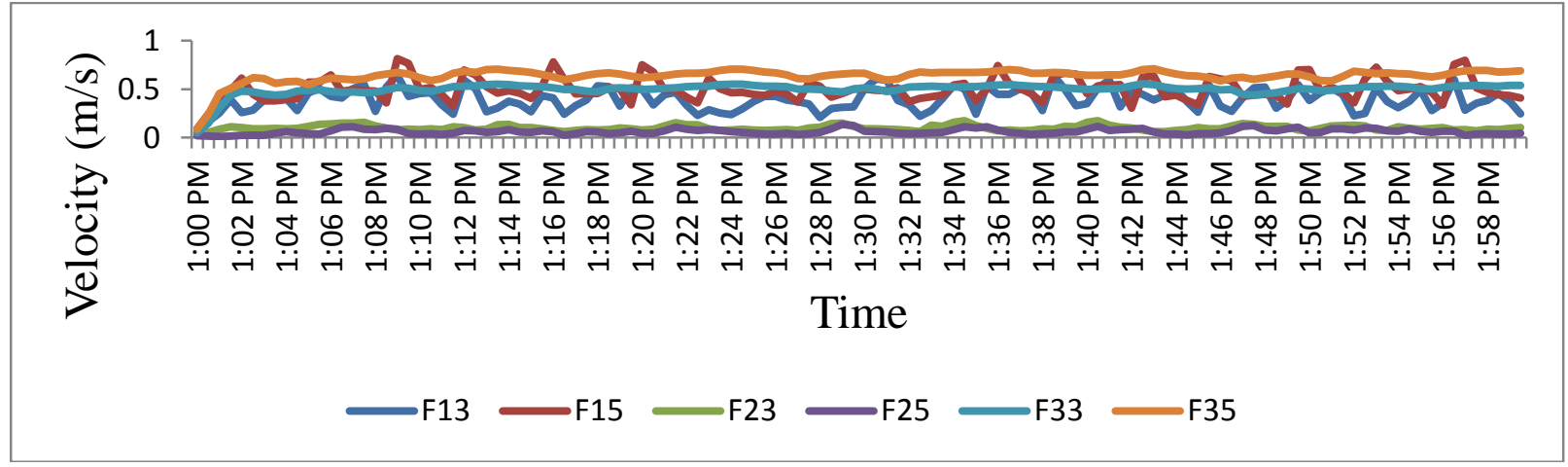

Fig. 18: Velocity vs. time

\section{For Temperature-}




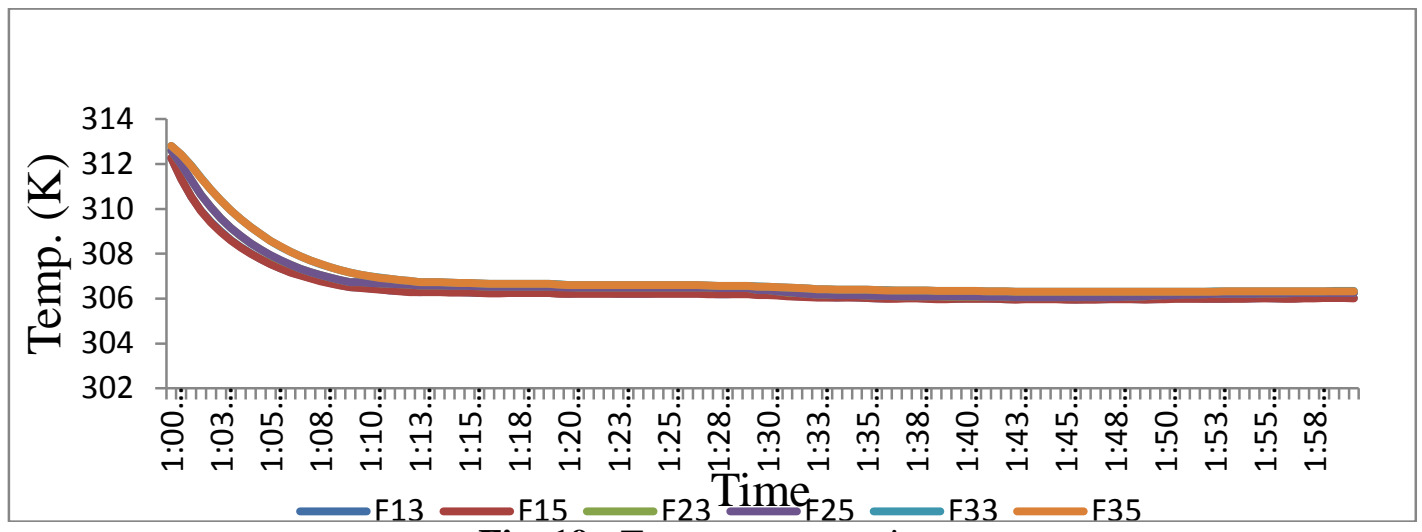

\section{Case-9}

Fig. 19: Temperature vs. time

The cooling temperature is taken as $26^{\circ} \mathrm{C}$. Two intake fans are working and three windows are open. The velocity and temperature at various points inside the office building is shown below:

\section{For Velocity-}

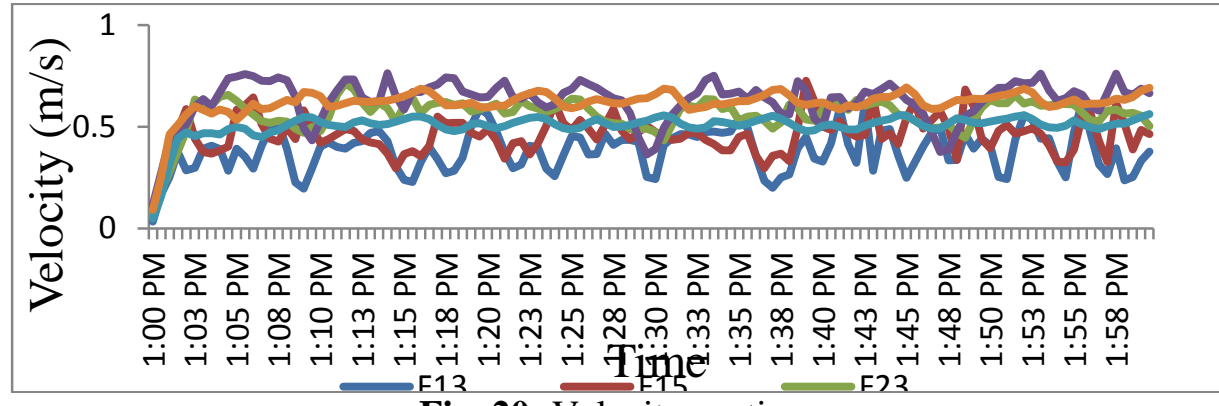

Fig. 20: Velocity vs. time

\section{For Temperature-}

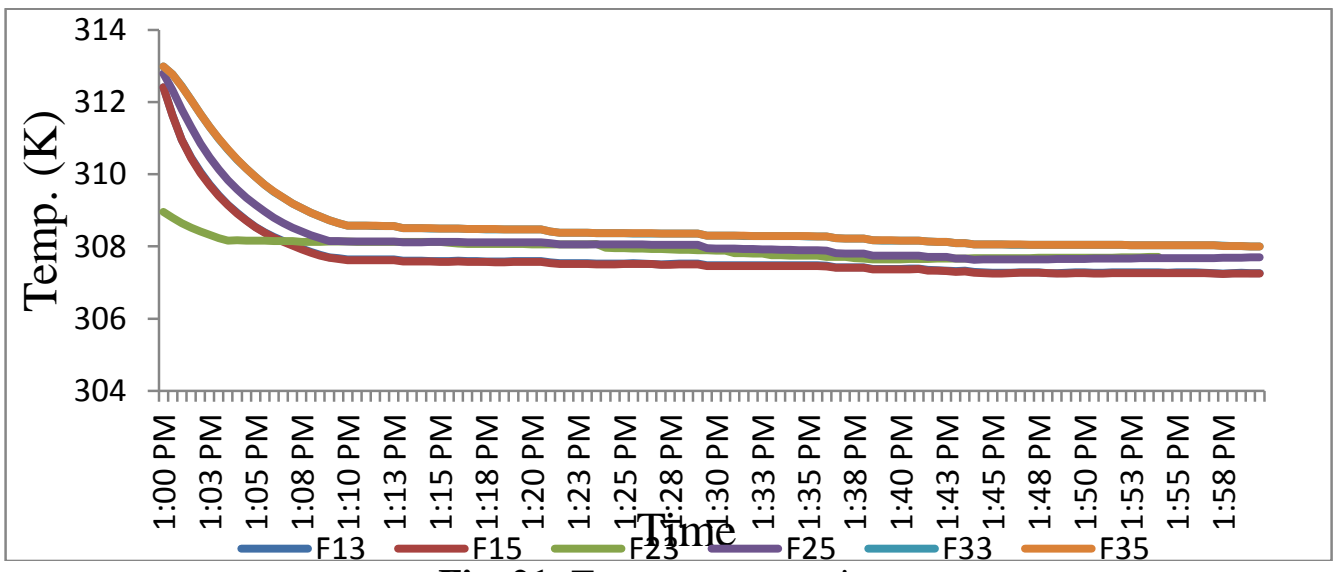

Fig. 21: Temperature vs. time

After the simulation the velocity and temperature are obtained at different points which are the response parameter of the study. These parameters are shown by the response table.

\section{Response Table:}


International Journal of Recent advances in Mechanical Engineering (IJMECH) Vol.4, No.2, May 2015

\begin{tabular}{|c|c|c|c|c|c|}
\hline $\begin{array}{c}\text { Case } \\
\text { No. }\end{array}$ & $\begin{array}{c}\text { Cooling } \\
\text { temp } \\
\mathbf{( \mathbf { c } )}\end{array}$ & $\begin{array}{c}\text { Intake } \\
\text { fan on }\end{array}$ & $\begin{array}{c}\text { Window } \\
\text { open }\end{array}$ & $\begin{array}{c}\text { Air } \\
\text { velocity } \\
(\mathbf{m} / \mathbf{s})\end{array}$ & $\begin{array}{c}\text { Air } \\
\text { temp. } \\
\mathbf{( k )}\end{array}$ \\
\hline 1 & 26 & 1 & 1 & 0.51 & 302.18 \\
\hline 2 & 26 & 2 & 2 & 0.47 & 303.17 \\
\hline 3 & 26 & 3 & 3 & 0.44 & 304.14 \\
\hline 4 & 28 & 1 & 2 & 0.50 & 304.47 \\
\hline 5 & 28 & 2 & 3 & 0.47 & 305.47 \\
\hline 6 & 28 & 3 & 1 & 0.50 & 305.19 \\
\hline 7 & 30 & 1 & 3 & 0.48 & 306.66 \\
\hline 8 & 30 & 2 & 1 & 0.50 & 306.45 \\
\hline 9 & 30 & 3 & 2 & 0.46 & 307.69 \\
\hline
\end{tabular}

Table 3: Response result from simulation

\section{Signal to Noise Ratio and Data Means Plot:}

\section{For Temperature:}

Smaller is better is considered.

Signal to noise ratio is simple technique to predict the effect of changing of factors according to their levels to find effect on product quality. In this study "smaller is better" option is adopted as quality indicator for $\mathrm{S} / \mathrm{N}$ ratio.

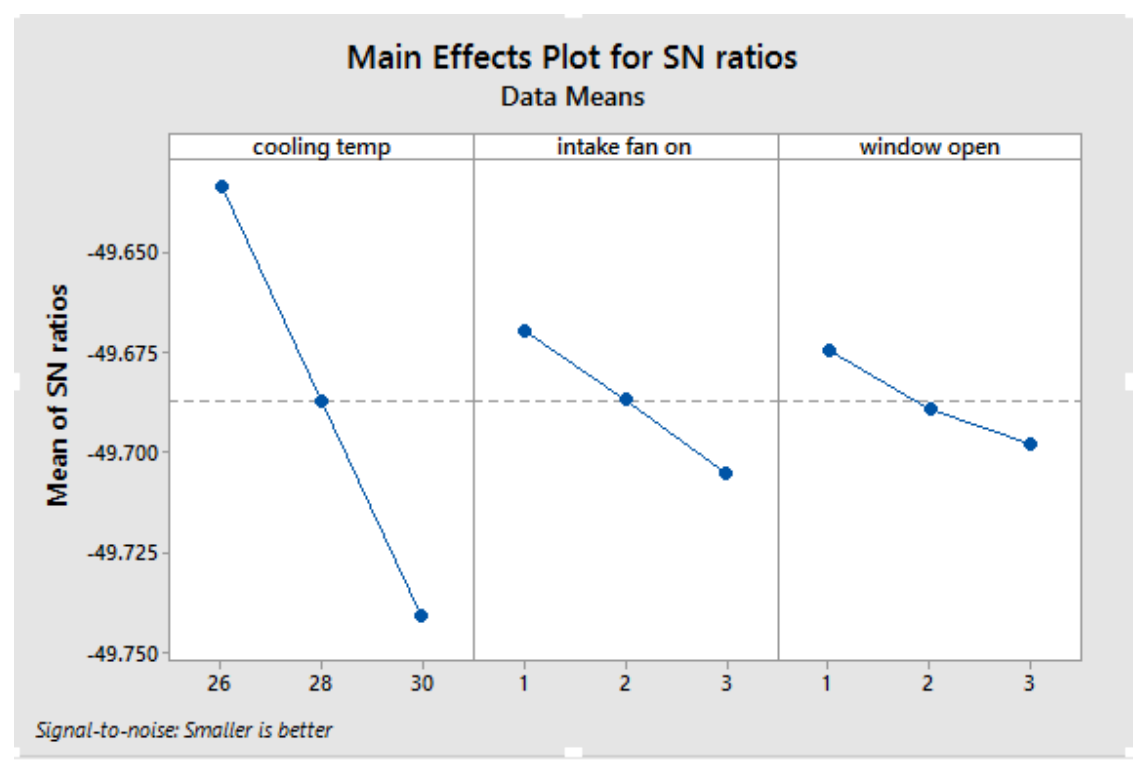

Fig. 22: SN ratio Plot 


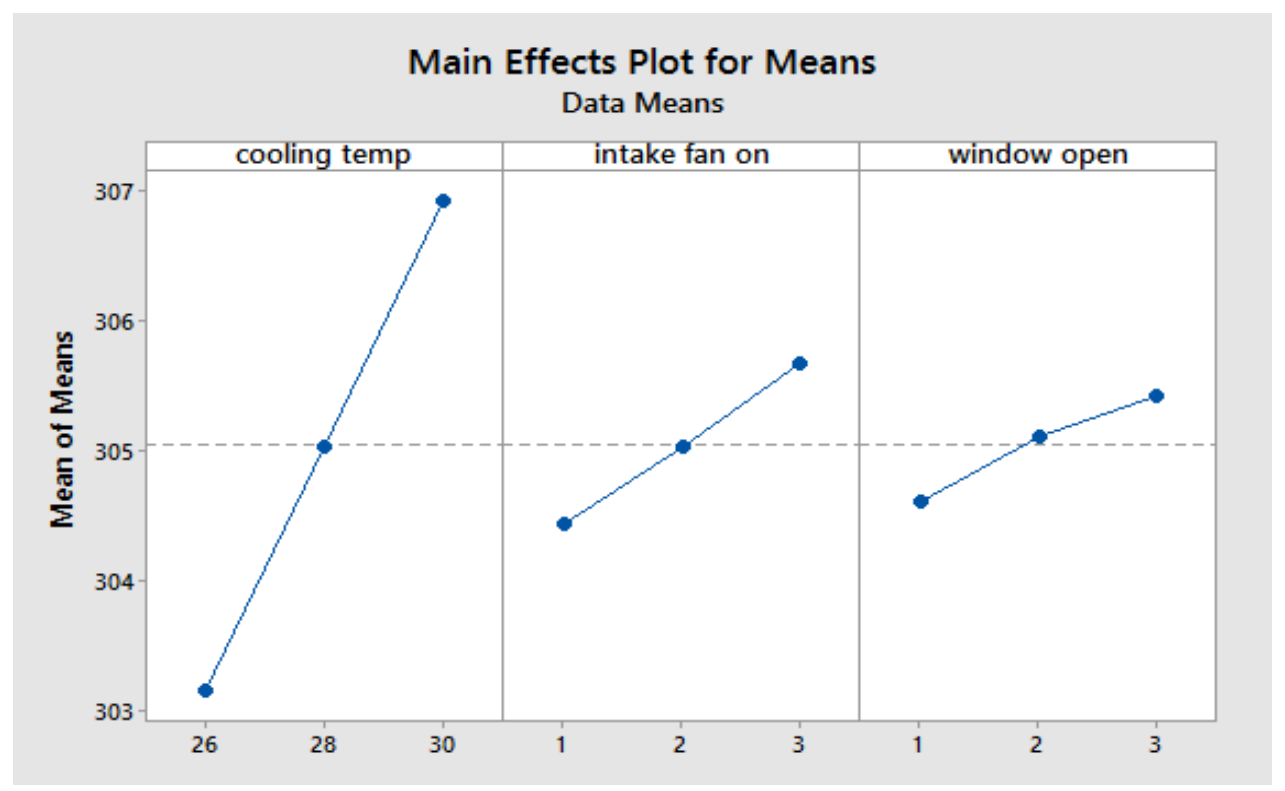

Fig. 23: Mains effect plot for means

\begin{tabular}{|c|c|c|c|}
\hline Level & $\begin{array}{c}\text { Cooling } \\
\text { temp } \\
\mathbf{(} \mathbf{c})\end{array}$ & $\begin{array}{c}\text { Intake } \\
\text { fan on }\end{array}$ & $\begin{array}{c}\text { Window } \\
\text { open }\end{array}$ \\
\hline 1 & 303.2 & 304.4 & 304.6 \\
\hline 2 & 305 & 305 & 305.1 \\
\hline 3 & 306.9 & 305.7 & 305.4 \\
\hline Delta & 3.8 & 1.2 & 0.8 \\
\hline Rank & $\mathbf{1}$ & $\mathbf{2}$ & $\mathbf{3}$ \\
\hline
\end{tabular}

Table 4: Response table for mean ratio

\begin{tabular}{|c|c|c|c|}
\hline Level & $\begin{array}{c}\text { Cooling } \\
\text { temp } \\
\left({ }^{0} \mathrm{c}\right) \\
\end{array}$ & $\begin{array}{l}\text { Intake } \\
\text { fan on }\end{array}$ & $\begin{array}{c}\text { Window } \\
\text { open }\end{array}$ \\
\hline 1 & -49.63 & -49.67 & -49.67 \\
\hline 2 & -49.69 & -49.69 & -49.69 \\
\hline 3 & -49.74 & -49.71 & -49.70 \\
\hline Delta & 0.11 & 0.04 & 0.02 \\
\hline Rank & 1 & 2 & 3 \\
\hline
\end{tabular}

Table 5: Response table for Signal to Noise ratio

\section{From SN Ratio:}

Best Case: A1 B1 C1 (Cooling Temp. $-26^{0}$ c, Intake Fan on-1, Window open-1)

Worse Case: A3 B3 C3 (Cooling Temp.-30º c, Intake Fan on-3, Window open-3)

Here $\mathrm{A}, \mathrm{B}$ and $\mathrm{C}$ represent factor cooling temp, intake fan on, window open respectively.

\section{For Velocity:}

Larger is better is considered. 


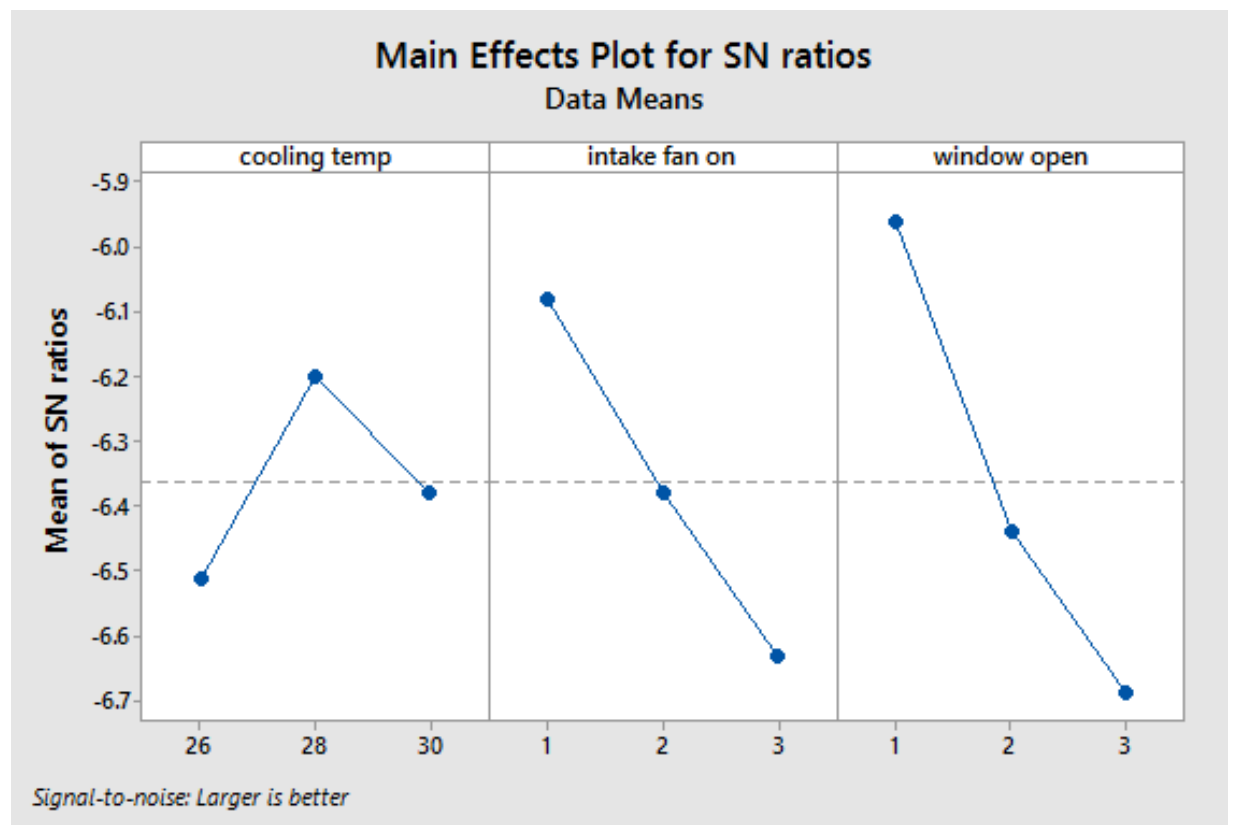

Fig. 24: SN ratio Plot

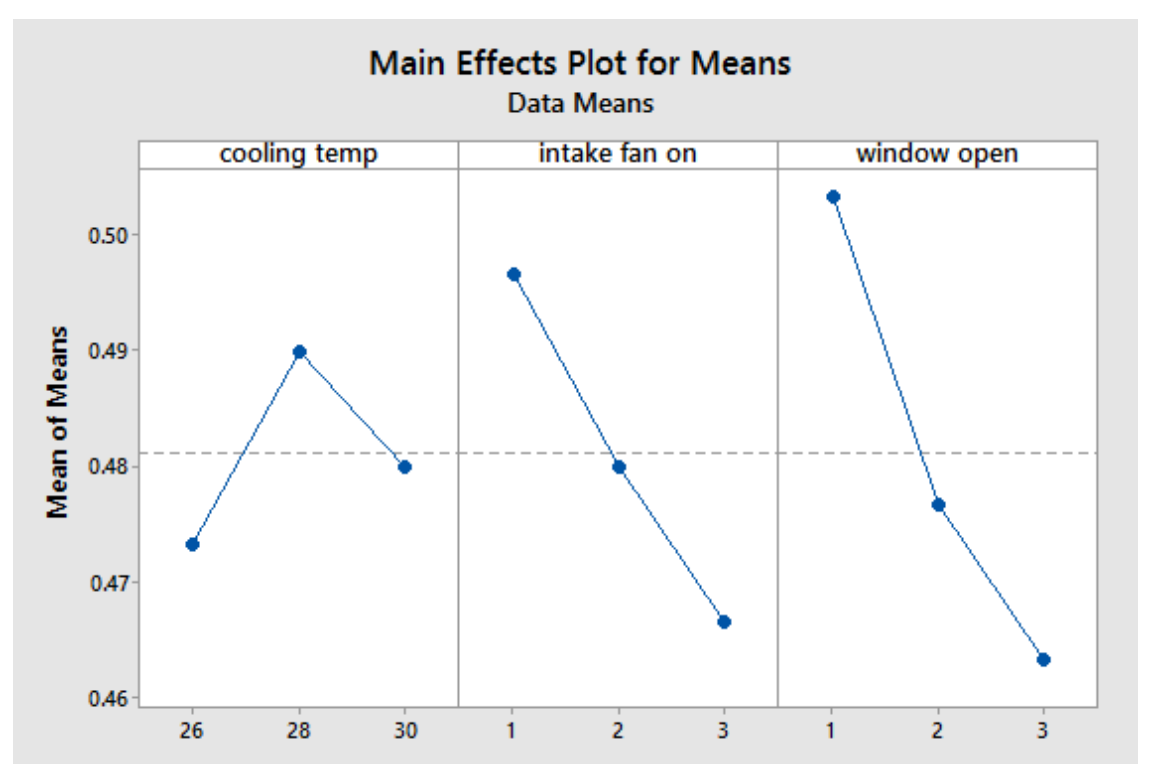

Fig. 25: Mains effects plot for means

\begin{tabular}{|c|c|c|c|}
\hline Level & $\begin{array}{c}\text { Cooling } \\
\text { temp } \\
\mathbf{(} \mathbf{0} \text { ) }\end{array}$ & $\begin{array}{c}\text { Intake } \\
\text { fan on }\end{array}$ & $\begin{array}{c}\text { Window } \\
\text { open }\end{array}$ \\
\hline 1 & 0.4733 & 0.4967 & 0.5033 \\
\hline 2 & 0.4900 & 0.4800 & 0.4767 \\
\hline 3 & 0.4800 & 0.4667 & 0.4663 \\
\hline Delta & 0.0167 & 0.0300 & 0.0400 \\
\hline Rank & $\mathbf{3}$ & $\mathbf{2}$ & $\mathbf{1}$ \\
\hline
\end{tabular}

Table 6: Response table for mean ratio

\begin{tabular}{|c|c|c|c|}
\hline Level & $\begin{array}{c}\text { Cooling } \\
\text { temp }\end{array}$ & $\begin{array}{c}\text { Intake } \\
\text { fan on }\end{array}$ & $\begin{array}{c}\text { Window } \\
\text { open }\end{array}$ \\
\hline
\end{tabular}




\begin{tabular}{|c|c|c|c|}
\hline & $\mathbf{(} \mathbf{c})$ & & \\
\hline 1 & -6.513 & -6.081 & -5.963 \\
\hline 2 & -6.200 & -6.379 & -6.441 \\
\hline 3 & -6.380 & -6.632 & -6.688 \\
\hline Delta & 0.313 & 0.551 & 0.725 \\
\hline Rank & $\mathbf{3}$ & $\mathbf{2}$ & $\mathbf{1}$ \\
\hline
\end{tabular}

Table 7: Response table for Signal to Noise ratio

\section{From SN Ratio:}

Best Case: A2 B1 C1 (Cooling Temp.-28 $8^{0}$, Intake Fan on-1, Window open-1)

Worse Case: A1 B3 C3 (Cooling Temp.-26 c, Intake Fan on-3, Window open-3)

Here $\mathrm{A}, \mathrm{B}$ and $\mathrm{C}$ represent factor cooling temp, intake fan on, window open respectively.

\section{Conclusion:}

A good agreement is observed by the CFD analysis of an office building using Taguchi method. It has been observed from all the graphs that the temperature is uniformly decrease but in velocity there is continuously variation. There were three levels and three factors. In total, nine cases were simulated and it is concluded that the best case for the thermal comfort of the building according to temperature is when the cooling temperature is $26^{\circ} \mathrm{C}$, and only one window is open and only one intake fan is on. Also from the response table above, it is concluded that the cooling temperature is the important factor among other factors for thermal comfort and best case according to velocity is when the cooling temperature is $28^{\circ} \mathrm{c}$, and only one intake fan \& one window open.

\section{Future Scope}

More convenient design tools and software can be used for this study which can provide the better thermal comfort results. Fuzzy logic can be used in this study which can provide comfort at minimum energy use. Ergonomics can be taken into consideration which determines metabolic heat production, an essential requirement and the assessment of thermal comfort.

\section{References:}

[1] Al-Rashidi Khaled, Loveday Dennis and Al-Mutawa Nawaf Impact of ventilation modes on carbon dioxide concentration levels in Kuwait classrooms [Journal] // Energy and Buildings. - 2012. - Vol. 87. - pp. 540-549.

[2] Barbason Mathieu and Reiter Sigrid Coupling building energy simulation and computational fluid dynamics: Application to a two-storey house in a temperate climate [Journal] // Building and Environment. - 2014. - Vol. 75. - pp. 30-39.

[3] Borge-Diez David [et al.] Passive climatization using a cool roof and natural ventilation for internally displaced persons in hot climates: Case study for Haiti [Journal] // Building and Environment. - 2013. - Vol. 59. - pp. 116-126.

[4] Caciolo Marcello [et al.] Development of a new correlation for single-sided natural ventilation adapted to leeward conditions [Journal] // Energy and Buildings. - 2013. - Vol. 60. - pp. 372-382. 
[5] Zhang Lin, T.T. Chow, C.F. Tsang, 9 November 2005, Effect of door opening on the performance of displacement ventilation in a typical office building.

[6] Fan Jianhua, Hviid Christian Anker and Honglu Yang Performance analysis of a new design of office diffuse ceiling ventilation system [Journal] // Energy and Buildings. - 2013. - Vol. 59. - pp. 73-81.

[7] Gloriant François [et al.] Modeling a triple-glazed supply-air window [Journal] // Building and Environment. - 2014. - Vol. 84. - pp. 1-9.

[8] Hajdukiewicz Magdalena, Geron Marco and Keane Marcus M. Calibrated CFD simulation to evaluate thermal comfort in a highly-glazed naturally ventilated room [Journal] // Building and Environment. - 2013. - Vol. 70. - pp. 73-89.

[9] Hirano Tomoko [et al.] A study on a porous residential building model in hot and humid regions: Part 1 -the natural ventilation performance and the cooling load reduction effect of the building model [Journal] // Building and Environment. - 2006. - Vol. 41. - pp. 21-32.

[10 ]Cruz-Salas M.V., J.A.Castillo and G.Huelsz Experimental study on natural ventilation of a room with a windward window and different wind exchanger [Journal] // Energy and Buildings. - 2014. - Vol. 84. - pp. 458-465. 